\title{
Formulasi Ransum Ayam Pedaging (Broiler) dan Pembuatan Feed Additives Herbal (Phytogenic) Berbasis Sumber Daya Pakan Lokal di Kabupaten Aceh Besar
}

\author{
Formulation of Feed and Feed Additives (Phytogenic) for Broiler \\ Chickens Based on Local Feed Resources in Aceh Besar District
}

\author{
Samadi $^{1, a}$, Sitti Wajizah ${ }^{1}$, Fitrah Khairi ${ }^{1}$, dan Ilham ${ }^{1}$ \\ ${ }^{1}$ Fakultas Pertanian Jurusan Peternakan Universitas Syiah Kuala \\ Jalan Hasan Krueng Kalee, No. 3, Darussalam, Banda Aceh \\ aemail: samadi177@unsyiah.ac.id
}

\begin{abstract}
Abstrak
Tujuan dari kegiatan pengabdian ini adalah untuk memberikan informasi formulasi pakan berdasarkan sumberdaya lokal dan pemberian imbuhan pakan herbal (phytogenic) kepada masyarakat. Kegiatan pengabdian ini dilaksanakan di dua desa yaitu Desa Tumbo Baro, Kecamatan Kuta Malaka (mitra FA Pronak), dan Desa Lamme Garot, Kecamatan Montasik Kabupaten Aceh Besar (mitra Kalasan Express). Kegiatan ini diharapkan dapat meningkatkan produktivitas ternak ayam broiler yang dipelihara oleh masyarakat serta meupakan upaya untuk meningkatkan sistem kekebalan tubuh dari ternak yang dipelihara masyarakat dengan memberikan feed additives herbal sebagai imbuhan pakan. Kegiatan pengabdian kepada masyarakat ini dilakukan secara bertahap, yaitu 1) Tahap persiapan kegiatan, 2) Penyuluhan dan pelatihan, 3) Pembuatan produk yang akan diaplikasikan pada peternak mitra. Hasil dari kegiatan ini adanya peningkatan pengetahuan peternak dalam memformulasi ransum ayam broiler dan penggunakan feed additive herbal sebagai imbuhan pakan dalam pemeliharaan ayam broiler. Kegiatan ini juga memberikan suatu produk ransum yang siap digunakan oleh peternak untuk memenuhi kebutuhan nutrisi dari ayam yang dipelihara.
\end{abstract}

Kata kunci: ayam pedaging, broiler, feed additive, herbal, ransum

\begin{abstract}
The purpose of this community service activity is to inform how to formulate feed based on local resources and inclusion of phytogenic as feed additives in broiler feed to animal farmers. The activities were conducted in two location (villages); Tumbo Baro village, Kuta Malaka subdistrict (FA Pronak) and Lamme Garot village, Montasik sub-district in Aceh Besar Region (Kalasan Express). With this activity, it is expected that the productivity and immune system of broilers raised by farmers were improved. The activities of this community service were divided in several steps; 1) Preparation, 2). Community education and training, 3) Practical to make products to be applied to the farmers groups in this community service. The results of this activity indicated that understanding of target groups (partners) to formulate feed and to produce feed additives in raising broilers was improved. In addition, by this activity, farmers were able to formulate and produce feed based on broiler requirements.
\end{abstract}

Keywords: meat chicken, broiler, feed additive, phytogenic, formulation 


\section{Pendahuluan}

Jamblang (Syzigium cumini (L.) merupakan salah satu tanaman berbuah lokal Indonesia, jamblang memiliki banyak manfaat hampir seluruh bagian tumbuhan tersebut telah diketahui kegunaannya secara tradisional (Sisilia Teresia Rosmala Dewi dan Sri Wahyuni., 2018).

Tanaman ini dilaporkan mengandung senyawa kimia antara lain suatu alkaloid, flavonoid, resin, tannin, dan minyak atsiri. Flavonoid merupakan salah satu metabolit sekunder yang terdapat pada tanaman ini. Senyawa ini dapat digunakan sebagai anti mikroba, obat infeksi pada luka, anti jamur, anti virus, anti kanker, dan anti tumor. Selain itu flavonoid juga dapat digunakan sebagai anti bakteri, anti alergi, sitotoksik, dan anti hipertensi (Gafur et al., 2011)

Produktivitas ayam broiler yang optimal dapat dicapai melalui pola pemeliharaan yang baik dengan menggunakan bibit unggul, pakan berkualitas dan manajemen pemeliharaan yang tepat. Dalam pemeliharaan ternak, terutama ternak unggas, biaya pakan merupakan pengeluaran yang paling besar, yaitu mencapai 70-80 \% dari biaya produksi (Sulfani et al., 2018). Upaya meningkatkan efesiensi pakan dapat dilakukan dengan melakukan formulasi ransum yang memenuhi kebutuhan nutrisi dan penggunaaan imbuhan pakan yang bertujuan untuk meningkatkan produktivitas ternak.

Imbuhan pakan yang umumnya digunakan untuk memacu pertumbuhan pada ayam broiler salah satunya adalah antibiotik (antibiotics growth promoters/AGP). Penggunaan antibiotik selain dapat meningkatkan efisiensi penggunaan pakan, juga dapat meningkatkan immunogenik dan meningkatkan berat badan ayam broiler sampai 100 gram/hari pada umur 6 minggu (Julendra et al., 2010).

Penggunaan antibiotik sebagai bahan aditif telah dilarang di Indonesia mulai Januari 2018, sesuai dengan Peraturan Menteri Pertanian No.14/PERMENTAN/PK.350/5/2017tentan g klasifikasi obat hewan. Penggunaan antibiotik dalam memacu pertumbuhan ternak dikhawatirkan menimbulkan residu antibiotik yang dapat menyebabkan resistensi bakteri sehingga membahayakan ternak dan berdampak buruk bagi kesehatan manusia yang mengonsumsinya, karena antibiotik yang digunakan merupakan produk semi sintetis. Sebagai bahan pengganti dari antibiotik dalam mempertahankan sistem kekebalan tubuh ternak serta untuk meningkatkan produktivitas ternak dapat digunakan bahan alternatif lain sebagai pengganti AGP yang mengandung growth promotor alami, salah satunya yaitu probiotik (Adzima et al., 2018).

Probiotik merupakan imbuhan pakan berupa mikroorganisme hidup non patogen yang dapat meningkatkan kerja sistem pencernaan, fungsi metabolisme, dan kesehatan inang pada umumnya (Nurhidayat, 2012). Probiotik juga dapat meningkatkan konsumsi pakan, meningkatkan laju pertumbuhan dan menurunkan feed convertion ratio (FCR) (Soeharsono, 2010).

Pengabdian kepada masyarakat yang dilakukan melibatkan dua mitra pengabdian, yaitu: Kalasan Expres dan FA Pronak. Kalasan Expres merupakan usaha peternakan secara mandiri yang berada di di Desa Lamme Garot, Kecamatan Montasik, Kabupaten Aceh Besar. Kalasan Expres yang melakukan kegiatan usaha di bidang peternakan ayam pedaging, sementara mitra ke-2 yaitu FA Pronak yang berada di Desa Tumbo Baro Kecamatan Kuta Malaka, Kabupaten Aceh Besar. Permasalahan yang terjadi pada mitra Kalasan Expres adalah penggunaan bahan pakan komersial dengan harga tinggi sehingga mengurangi pendapatan peternak, formulasi pakan yang belum optimal dan perlu untuk ditingkatkan, dan pengemasan pakan yang tidak memenuhi standard. Pelarangan terhadap penggunaan antibiotik sebagai imbuhan pakan menginisiasi Mitra kedua (FA Pronak) untuk menghasilkan penganti antibiotik sebagai imbuhan pakan seperti probiotik. FA Pronak telah dijadikan Mitra pada tahun pertama kegiatan pengabdian masyarakat dengan menggunakan produk Mikro Organisme Lokal (MOL) sebagai 
penganti antibiotik, pada tahun ke dua FA Pronak dilibatkan lagi untuk pengembangan produk selanjutnya dan penggunaan alternatif imbuhan pakan dari bahan pakan herbal yang tersedia disekitar Aceh. Peningkatan pengetahuan Mitra FA Pronak bagaimana mendapatkan extrak berbagai bahan pakan herbal lokal yang dapat dijadikan sebagai imbuhan pakan pada usaha peternakan diharapkan dapat tercapai/ perlu dilakukan.

Berdasarkan permasalahan yang dihadapi oleh Mitra yang dilibatkan dalam kegiatan pengabdian masyrakat ini ada beberapa solusi yang ditawarkan. Solusi yang ditawarkan berupa: pembinaan berkaitan dengan formulasi pakan berdasarkan kebutuhan, pengetahuan tentang manajemen beternak ayam broiler yang benar dan baik untuk meningkatkan produktivitas ternak yang dipelihara. Solusi lainnya adalah melakukan pembinaan pembuatan bahan pakan herbal phytogenic dan peningkatan produk MOL sebagai sumber bahan probiotik agar produksi yang dihasilkan optimal, informasi tentang berbagai sumber bahan phytogenik yang dapat digunakan sebagai sumber imbuhan pakan, peningkatan pengetahuan Mitra FA Pronak bagaimana mendapatkan ekstrak berbagai bahan pakan herbal lokal yang dapat dijadikan sebagai imbuhan pakan pada usaha peternakan.

\section{Metode Pelaksanaan}

Kegiatan pengabdian kepada masyarakat yang berbasis produk ini dilakukan dengan metode penyuluhan dan pelatihan, ada beberapa tahapan yang dilaksanakan, yaitu:

1. Penyuluhan dan pelatihan

Kegiatan penyuluhan dan pembekalan serta pelatihan dilakukan secara luring dan daring dengan mematuhi protokol kesehatan dalam mencegah terjadinya penularan covid19.

2. Demonstrasi/Pelatihan

Demonstrasi/pelatihan

yang dilakukan adalah metode pembuatan pakan dan formulasi ransum yang seimbang serta pembuatan feed additive sebagai imbuhan pakan yang berasal dari bahan lokal. Kegiatan pengabdian kepada masyarakat dilakukan secara bersama di lingkungan kampus dan selanjutnya memberikan produk hasil kegiatan untuk diimplementasikan pada usaha ayam broiler mitra pengabdian.

\section{Hasil dan Pembahasan}

Beberapa hasil yang diperoleh dalam kegiatan pengabdian kepada masyarakat yang berbasis produk sebagai berikut.

\section{Pembuatan Feed Additives (Pytogenic) untuk Ayam Pedaging (Broiler)}

Feed additive merupakan suatu bahan pakan yang ditambahkan dalam jumlah yang sedikit ke dalam ransum dengan tujuan tertentu. Tujuan penambahan feed additive di dalam ransum adalah untuk mendapatkan pertumbuhan ternak yang optimal dan meningkatkan produktivitas ternak.

Feed additive dibagi menjadi dua jenis yaitu feed additive alami dan sintetis (Wahju, 2004). Menurut Widodo (2002) fungsifeed additive adalah untuk memperbaiki pakan, meningkatkan efisiensi pakan dan perbaikan kualitas produksi ternak.

\section{Prosedur pembuatan Feed Additives (Pytogenic)}

Tahapan Ekstraksi Daun Jamblang

1. Daun Jamblang dikeringkan dengan cara dijemur atau pakai oven pengering

2. Setelah kering daun jamblang digiling menggunakan mesin penggiling/disk mill

3. Daun jamblang ditimbang dan dimasukkan ke dalam wadah

4. Selanjutnya ditambahkan alkohol 95\% dan dicampurkan ke dalam daun jamblang dan diaduk hingga merata, kemudian tutup wadah dengan rapat

5. Diamkan selama 2 hari

6. Setelah 2 hari, daun jamblang tersebut diperas menggunakan 
serbet dan disaring menggunakan kertas saring

7. Cairan hasil saringan ditampung ke dalam botol penampung

8. Selanjutnya dilakukan ekstraksi menggunakan alat evakurator untuk menguapkan etanol sampai menghasilkan ekstrak jamblang.

\section{Penyusunan Ransum Ayam Pedaging (Broiler)}

Dalam rangka mencegah terjadinya penularan Covid-19, dalam hal penyusunan ransum ayam pedaging (Broiler) untuk kegiatan pengabdian kepada masyarakat berbasis produk ini, maka kami melakukan pembahasan penyusunan ransum ayam pedaging secara daring menggunakan aplikasi zoom meeting.

Gambar 1 merupakan kegiatan penyusunan ransum dengan metode linear program menggunakan aplikasi FeedLive yang dilakukan secara daring via zoom meeting.

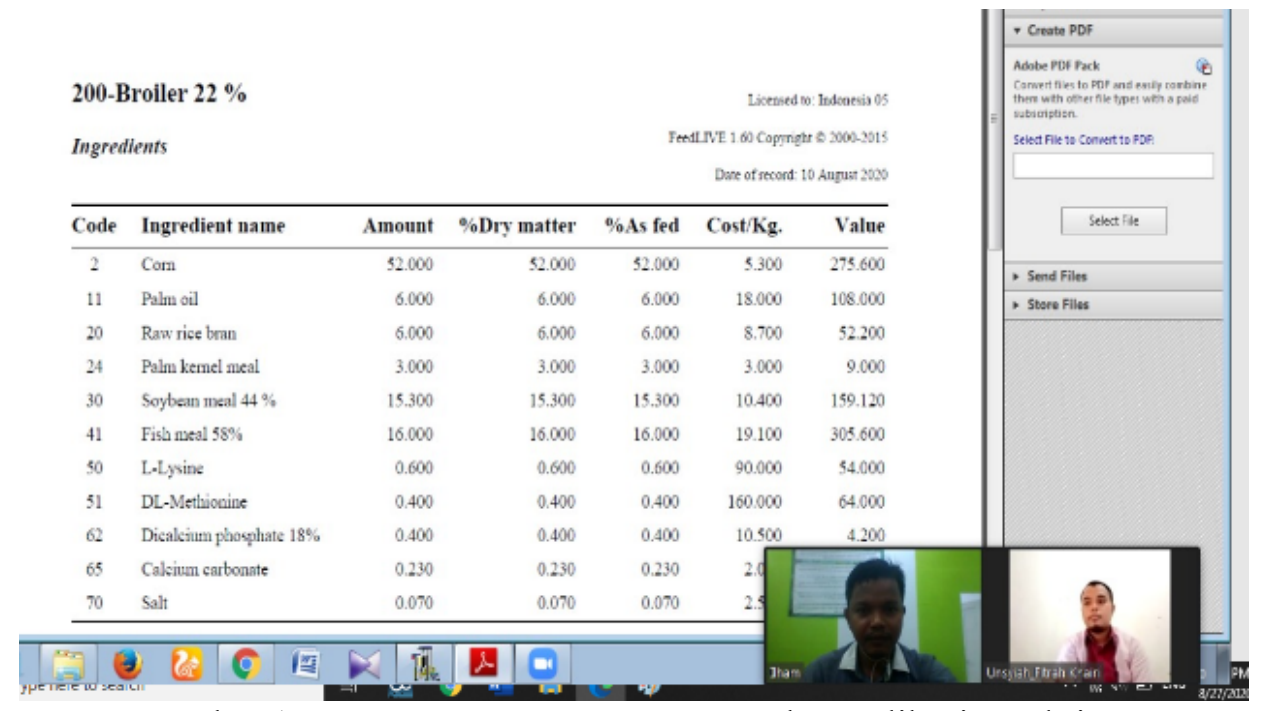

Gambar 1. Penyusunan ransum menggunakan aplikasi FeedLive

\section{Hasil Penyusunan Ransum Ayam Pedaging (Broiler)}

Penyusunan ransum merupakan suatu metode untuk menyamakan kandungan nutrisi bahan pakan yang dipilih dengan kebutuhan ayam pedaging, prinsipnya hanya menyamakan atau membuat seimbang kandungan nutrisi di dalam ransum sesuai dengan kebutuhan dari ternak itu sendiri sehingga terdapat beberapa metode penyusunan yang dapat dilakukan. Untuk memperoleh ransum yang berkualitas, peternak perlu mengetahui teknik penyusunan ransum yang biasa berlaku di dunia perunggasan dan memilih salah satu metode yang sesuai dengan situasi dan kondisi peternak sendiri, sehingga diharapkan bisa didapat ransum yang memenuhi kebutuhan gizi ayam tetapi dengan harga yang relatif murah. Hasil penyusunan ransum ayam pedaging (broiler) untuk kegiatan pengabdian kepada masyarakat berbasis produk dapaat dilihat pada uraian berikut.

\section{Komposisi Bahan Pakan dalam Ransum Ayam Pedaging (Broiler)}

Secara umum ada beberapa bahan pakan yang biasa digunakan dalam penyusunan ransum ternak unggas seperti bahan pakan sumber energi, bahan pakan sumber protein dan bahan pakan sumber vitamin dan mineral untuk memenuhi kebutuhan dari ternak, bahan pakan tersebut diantaranya adalah jagung, dedak, tepung ikan, bungkil kedelai, minyak sayur, bungkil kelapa, tepung kapur, batuan fosfat, asam amino sintetis (terutama metionin dan lisin) dan campuran vitamin-mineral.

Salah satu contoh dari peran pakan yang mempengaruhi produksi dari ternak adalah kandungan asam-asam amino 
esensial (Samadi dan Liebert, 2007a; 2007b dan 2008).

Beberapa jenis bahan pakan yang merupakan produksi lokal juga banyak tersedia yang dapat digunakan untuk penysusun ransum, tetapi jumlah dan penyebaran bahan tersebut tidak merata di setiap daerah, hal ini juga akan menyebabkan harga dari beberapa bahan pakan akan berbeda-beda setiap daerah. Harga dari setiap bahan pakan juga akan menentukan kelayakan dalam melakukan formulasi ransum.

Penggunaan bahan pakan lokal untuk ransum unggas perlu diperhatikan dari segi harga yang lebih murah, ketersedian bahan pakan tersebut secara berkesinambungan, kandungan nutrisi dari bahan pakan yang digunakan, serta adanya faktor pembatas dalam penggunaan bahan pakan tersebut.

Berikut komposisi bahan pakan dalam ransum ayam pedaging yang dibuat menggunakan aplikasi FeedLive .

Tabel 1. Komposisi bahan pakan penyusun

200-Broiler $22 \%$

Licensed to: Indonesia 05

Ingredients

FeedLIVE 1.60 Copyright $\odot$ 2000-2015

Date of record: 10 August 2020

\begin{tabular}{llrrrrr}
\hline Code & Ingredient name & Amount & \%Dry matter & \%As fed & Cost/Kg. & Value \\
\hline 2 & Corn & 52.000 & 52.000 & 52.000 & 5.300 & 275.600 \\
11 & Palm oil & 6.000 & 6.000 & 6.000 & 18.000 & 108.000 \\
20 & Raw rice bran & 6.000 & 6.000 & 6.000 & 8.700 & 52.200 \\
24 & Palm kernel meal & 3.000 & 3.000 & 3.000 & 3.000 & 9.000 \\
30 & Soybean meal 44 \% & 15.300 & 15.300 & 15.300 & 10.400 & 159.120 \\
41 & Fish meal 58\% & 16.000 & 16.000 & 16.000 & 19.100 & 305.600 \\
50 & L-Lysine & 0.600 & 0.600 & 0.600 & 90.000 & 54.000 \\
51 & DL-Methionine & 0.400 & 0.400 & 0.400 & 160.000 & 64.000 \\
62 & Dicalcium phosphate 18\% & 0.400 & 0.400 & 0.400 & 10.500 & 4.200 \\
65 & Calcium carbonate & 0.230 & 0.230 & 0.230 & 2.000 & 0.460 \\
70 & Salt & 0.070 & 0.070 & 0.070 & 2.500 & 0.175 \\
\hline & Total & $\mathbf{1 0 0 . 0 0 0}$ & $\mathbf{1 0 0 . 0 0 0}$ & $\mathbf{1 0 0 . 0 0 0}$ & & $\mathbf{1 . 0 3 2 . 3 5 5}$ \\
\hline
\end{tabular}

Cost/Kilogram. 10.324 Baht

\section{Komposisi Kandungan Nutrisi Ransum Ayam Pedaging (Broiler)}

Komposisi kandungan nutrisi dari suatu bahan pakan perlu diketahui sebelum melakukan formulasi ransum, dalam melakukan formulasi ransum memerlukan beberapa informasi seperti jenis bahan pakan yang akan digunakan, serta informasi mengenai kandungan nutrisi dari masingmasing bahan pakan yang akan digunakan, informasi tersebut diperlukan untuk memenuhi nutrisi yang dibutuhkan sesuai dengan kebutuhan ternak.

Pemberian pakan harus disesuaikan dengan kebutuhan ternak dan dilakukan secara teratur dengan jumlah yang sesuai.
Kelebihan atau kekurangan pemberian akan berdampak kurang baik pada ternak dan berpengaruh pada efisiensi produksi (Rahardi dan Hartono, 2003). Hal yang perlu diperhatikan dalam pemberian pakan adalah tercukupinya kebutuhan energi, protein, lemak, vitamin, mineral dan air (Subekti, 2009). Kebutuhan zat tersebut bagi ternak sangat dibutuhkan untuk kebutuhan aktivitas (maintenance), pertumbuhan dan perkembangan

Kandungan nutrisi ransum ayam pedaging yang telah disusun dengan bantuan aplikasi FeedLive dapat dilihat pada Tabel 2. 
Tabel 2. Kandungan nutrisi ransum ayam pedaging (broiler)

\begin{tabular}{cllrrr}
\multicolumn{1}{l}{ Nutrient } & \multicolumn{1}{l}{ Calculated } & Minimum & Maximum \\
\hline Code & Nutrient name & Unit & 3.235 .470 & 3.200 .000 & 3.300 .000 \\
\hline 1 & ME. for Poultry & Cal/Kg. & 22.098 & 22.000 & 23.000 \\
3 & Protein & $\%$ & 10.455 & & 8.000 \\
6 & Fat & $\%$ & 3.581 & 2.500 & 4.000 \\
7 & Fiber & $\%$ & 1.329 & 0.990 & 1.200 \\
8 & Calcium & $\%$ & 0.854 & 0.680 & \\
9 & Total Phosphorus & $\%$ & 0.579 & 0.450 & \\
10 & Avail. P for Poultry & $\%$ & 0.411 & 0.280 & 0.500 \\
12 & Salt & $\%$ & 1.358 & 1.030 & \\
13 & Arginine & $\%$ & 1.710 & 1.200 & \\
18 & Lysine & $\%$ & 1.134 & 0.880 & \\
19 & Methionine + Cystine & $\%$ & 0.845 & 0.500 & \\
20 & Methionine & $\%$ & 0.820 & 0.750 & \\
23 & Threonine & $\%$ & 0.237 & 0.220 & \\
24 & Tryptophan & $\%$ & & & \\
\hline
\end{tabular}

\section{Kesimpulan}

Kesimpulan yang diperoleh pada kegiatan Pengabdian kepada masyarakat yang berbasis produk ini adalah meningkatkan pengetahuan masyarakat dalam penggunaan feed additive herbal dalam pemeliharaan ayam broiler sebagai imbuhan pakan dan memahami metoda dalam melakukan formulasi ransum ayam broiler.

Berdasarkan data yang ditampilkan pada Tabel 3 diatas dapat dilihat bahwa kegiatan pengabdian yang telah dilaksanakan dapat meningkatkan tingkat pemahaman masyarakat/mitra pengabdian yang dilaksanakan di Kabupaten Aceh Besar

Tabel 3. Hasil analisis kuesioner pre-test dan post-test.

\begin{tabular}{|c|c|c|c|}
\hline \multirow[b]{2}{*}{ No. } & \multirow[b]{2}{*}{ Jenis Pengetahuan } & \multicolumn{2}{|c|}{ Tingkat Pemahaman (\%) } \\
\hline & & $\begin{array}{c}\text { Sebelum } \\
\text { Kegiatan Pengabdian }\end{array}$ & $\begin{array}{c}\text { Setelah } \\
\text { Kegiatan Pengabdian }\end{array}$ \\
\hline 1 & Kebutuhan nutrisi ayam pedaging & 70,00 & 95,00 \\
\hline 2 & $\begin{array}{l}\text { Jenis-jenis bahan pakan sumber protein dan } \\
\text { energi untuk ayam pedaging }\end{array}$ & 75,00 & 100,00 \\
\hline 3 & $\begin{array}{l}\text { Jenis-jenis bahan pakan sumber vitamin dan } \\
\text { mineral untuk ayam pedaging }\end{array}$ & 85,00 & 100,00 \\
\hline 4 & $\begin{array}{l}\text { Fungsi feed additive dan Jenis-jenis pakan } \\
\text { feed additive }\end{array}$ & 65,00 & 100,00 \\
\hline 5 & Cara pembuatan feed additive & 55,00 & 100,00 \\
\hline 6 & Formulasi ransum ayam pedaging & 25,00 & 90,00 \\
\hline
\end{tabular}




\section{Daftar Pustaka}

Adzima, V., Nurliana dan Samadi. 2018. Pengaruh pemberian ampas kedelai dan bungkil inti sawit (AKBIS) yang difermentasi dengan Aspergillus niger terhadap bakteri usus broiler. Agripet. 18(1): 48-56.

Gafur, Maryati, dkk., 2011, Isolasi dan Identifikasi Senyawa Flavonoid dari Daun Jamblang (Syzygium cumini). Universitas Gorontalo.

Julendra, H., Zuprizal dan Supadmo. 2010. Penggunaan tepung cacing tanah (Lumbricus rubellus) sebagai aditif pakan terhadap penampilan produksi ayam pedaging, profil darah, dan kecernaan protein. Buletin Peternakan. 34(1): 21-29.

Nurhidayati, N. 2012. Mikroenkapsulasi probiotik Lactobacillus plantarum dan analisis ekspresi gen mannose spesific adhesin. Widyariset. 15(2): 249-256.

Rahardi, F dan R. Hartono. 2003. Agribisnis Peternakan. Penebar Swadaya, Jakarta.

Samadi dan Liebert, F. 2007a. Lysine requirement of fast growing chickens-Effects of sex, age, level of protein deposition and lysine efficiency. The Journal of Poultry Science. 44:63-72.

Samadi dan Liebert, F. 2007b. Threonine Requirement of Slow-Growing Male
Chickens Depends on Age and Dietary Efficiency of Threonine Utilization. Poultry Science 86(6): $1140-1148$.

Samadi dan Liebert, F. 2008. Modelling the optimal lysine to threonine ratio in growing chickens depending on age and efficiency of dietary amino acid utilisation. Br Poult Sci. 2008 Jan;49(1):45-54.

Sisilia Teresia Rosmala Dewi dan Sri Wahyuni. 2018. Uji Efek Anti Inflamasi Rebusan Daun Jamblang (Syzygium Cumini) pada Mencit (Mus Musculus). Media Farmasi Vol. XIV. No.1

Soeharsono. 2010. Probiotik Basis Ilmiah, Aplikasi dan Aspek Praktis. Widya Padjajaran. Bandung.

Subekti, E. 2009. Ketahanan pakan ternak indonesia. Madiagro. 5(2):63-71.

Sulfani, M. I., Sugiharto dan Yudiarti, T. 2018. Total bakteri asam laktat dan Coliform pada ileum dan sekum ayam broiler yang diberi Spirulina platensis dengan lama pemberian berbeda. Jurnal Ilmu-Ilmu Peternakan. 28(1): $65-72$.

Wahju, J. 2004. Ilmu Nutrisi Unggas. Gadjah Mada University Press, Yogyakarta.

Widodo, W., 2002. Nutrisi dan Pakan Unggas Kontekstual. Universitas Muhammadiyah Malang, Malang. 